\title{
3-[(E)-(4-Hydroxy-3-methoxybenzylidene)amino]-2- thioxoimidazolidin-4-one as Snail1 Inhibitor with Anticancer and Anti-migratory Properties Against Colorectal Cancer
}

\author{
DHANYA SUNIL $^{1 *}$, C. RANJITHA $^{1}$ and M. RAMA ${ }^{1}$ and S. BALAJI ${ }^{2}$ \\ ${ }^{1 *}$ Department of Chemistry, ${ }^{2}$ Department of Biotechnology, \\ Manipal Institute of Technology, Manipal University- 576 104, India \\ dhanyadss3@gmail.com
}

Received 31 May 2014 / Accepted 29 June 2014

\begin{abstract}
Colorectal cancer is the third leading cause of cancer related deaths in humans. Research is going on to increase the treatment options of colon cancer with decreased side effects. Four imidazolidinones were synthesized by the cyclization reaction between Schiff bases and ethylchloroacetate and were characterized by advanced spectral techniques and CHN analysis. The cytotoxic and anti-migratory properties of imidazolidinones against HCT116 (human colorectal adenocarcinoma) cells were studied using Sulphorhodamine-B (SRB) assay and wound healing assay respectively. 3-[(E)-(4-Hydroxy-3-methoxybenzylidene)amino]-2-thioxoimidazolidin-4-one (2d) displayed excellent cytotoxicity with low $\mathrm{IC}_{50}$ in $\mathrm{SRB}$ assay. The wound gap observed on treatment with 2d indicated the reduced motility of HCT116 cells. Snail1, an E-Cadherin repressor plays an important role in epithelial to mesenchymal transition which influences metastatic cancer and hence, a molecular target in cancer treatment for anti-invasive drugs. The effective binding of 2d into the active site of snail1 in docking studies, suggests it to be a promising anti-neoplastic agent in the treatment of colorectal cancer.
\end{abstract}

Keywords: Oxazepines, Cytotoxicity, Metastases, Snail1

\section{Introduction}

Colorectal adenocarcinoma continues to be a major killer in humans in developing as well as developed countries. Metastases is the major cause of cancer-associated deaths that occurs when cancer cells detach from the primary tumor and disseminate via the circulation and invade surrounding tissues to form the secondary tumors. Snaill induced epithelial-tomesenchymal transition (EMT), involving repression of E-cadherin, converts epithelial cells into mesenchymal cells with migratory properties that contribute to the acquisition of invasive properties in epithelial tumors ${ }^{1-3}$. In cancer, snail1 protein induced EMT facilitates the delamination of cells from the primary tumor, intravasation into lymph or blood vessels, favoring invasion and confers selective advantage to migratory malignant cells to metastasize ${ }^{4-7}$. Advances in the last few years have led to our understanding that snaill is a 
new potential target of anti-invasive drugs, owing to its association with dedifferentiated metastatic tumors of different origins. Invasion of cancer cells is also favored by the angiogenic properties of snail ${ }^{8}$.

Snaill inactivation could prevent invasiveness and make invasive cells more susceptible to destruction. Snail physically interacts with the lysine specific histone demethylase (LSD1) via the SNAG domain, and recruits LSD1 to epithelial gene promoters. LSD1 is essential for snail-mediated transcriptional repression and in its absence; Snail fails to repress its targets. These results underline the critical role of LSD1 in snail-dependent transcriptional repression of epithelial markers and suggest that a suitable inhibitor could prevent LSD1 from complexing with snaill and thereby reduce cancer progression.

Schiff bases, compounds that contain an azomethine group, formed by condensation of primary amine with the carbonyl products represent valuable intermediates in organic synthesis and have attracted much interest in the development of pharmacologically active compounds with potent antibacterial ${ }^{9,10}$, antifungal ${ }^{11,12}$ and anticancer ${ }^{13}$ properties. Schiff bases appear to be important intermediates in a number of enzymatic reactions involving interaction of enzyme with an amino or a carbonyl group of the substrate. 2-thioxo-4imidazolidinone are a class of heterocycles having a ring that contains two groups-thion and carbonyl at positions 2 and 4 respectively that possess wide spectrum of therapeutic activities such as anti-bacterial ${ }^{14}$, anti-inflammatory ${ }^{15}$ and anti-tumor ${ }^{16}$. Thus, the present study focuses on the synthesis of imidazolidinones with anti-tumor and anti-migratory properties as effective inhibitors of snaill and could presumably prevent LSD1-Snail1 complex formation, responsible for cancer progression during pathogenic conditions.

\section{Experimental}

(2E)-2-(Substituted)hydrazinecarbothioamide (Schiff's bases) 1a-d were synthesized by the amino condensation between hydrazinecarbothioamides and four different aromatic aldehydes ${ }^{17}$. Four new imidazolidinones were prepared by the reaction between Schiff bases and ethylchloroacetate in presence of anhydrous sodium acetate ${ }^{18}$. The synthetic pathway is depicted in Scheme 1.

Thin layer chromatography of imidazolidinones on $0.25 \mathrm{~mm}$ silica gel plates was performed using a 1:9 mixture of ethyl acetate and hexane mixture as eluent. Melting points of imidazolidinones were determined by open capillary method and were uncorrected. The elemental analysis of the newly synthesized compounds was carried out in Flash thermo 1112 series $\mathrm{CHN}$ analyser.

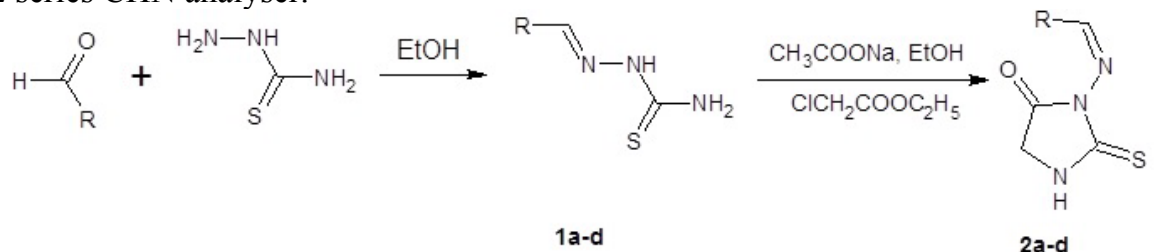

$$
\begin{array}{cl}
\text { Comp. No } & \multicolumn{1}{c}{\mathrm{R}} \\
\text { 1a, 2a } & \text { 4-hhdroxy phenyl } \\
\text { 1b, 2b } & \text { 3-indolyl } \\
\text { 1c. 2c } & \text { 2,3-dimedroxy phenyl } \\
\text { 1d, 2d } & \text { 2-methoxy-3-hydoxy phenyl }
\end{array}
$$

Scheme 1. Synthetic route for (2E)-2-(substituted)hydrazinecarbothioamide (1a-d) and 3 - $\{[(Z)-(4-$ substitutedphenyl)methylidene $]$ amino $\}$-2-thioxoimidazolidin-4-one (2a-d) 


\section{Anticancer activity}

The synthesized imidazolidinones were studied for their anticancer properties in HCT-116 cells, procured from NCCS, Pune and cultured in Dulbecco's Modified Eagles Medium (DMEM) with $10 \%$ Fetal Bovine Serum (FBS) at $37{ }^{\circ} \mathrm{C}$ in $5 \% \mathrm{CO}_{2}$ atmosphere.

\section{Sulphorhodamine-B (SRB) assay}

Test solutions of imidazolidinones were dissolved in $0.2 \%$ DMSO and diluted with media prior to the experiment. $10^{4}$ cells/well in $100 \mu \mathrm{L}$ of medium were seeded in 96well plates and kept overnight for 24 hours at $37^{\circ} \mathrm{C}$ in $\mathrm{CO}_{2}$ incubator. The cells were then exposed to different concentrations $(12.5-200 \mu \mathrm{g} / \mathrm{mL} ; 100 \mu \mathrm{L} /$ well $)$ of imidazolidinones. Control wells were treated with medium containing $0.2 \%$ DMSO. After $48 \mathrm{~h}, 50 \mu \mathrm{L}$ of ice cold $30 \%$ trichloroacetic acid was added to each well, and incubated at $4{ }^{\circ} \mathrm{C}$ for $1 \mathrm{~h}$ and washed with distilled water. $50 \mu \mathrm{L}$ of $0.05 \% \mathrm{w} / \mathrm{v}$ (in $1 \%$ acetic acid) SRB solution was added to each well and incubated for $30 \mathrm{~min}$ in dark. The wells were rinsed with $1 \%$ acetic acid, dried, $10 \mathrm{mM}$ Tris base was added to each well and the absorbance was read at $540 \mathrm{~nm}$ in a multi-well plate reader (ELx800, BioTek Instruments Inc., Winooski, VT, USA). The percentage of growth inhibition was calculated using the formula:

$$
\% \text { Cytotoxicity }=[(\mathrm{AC}-\mathrm{AB})-(\mathrm{AT}-\mathrm{AB})] /(\mathrm{AC}-\mathrm{AB})
$$

Where, $\mathrm{AC}, \mathrm{AB}$ and $\mathrm{AT}$ are absorbance of control, blank and test respectively ${ }^{19}$.

\section{Scratch wound assay}

Cells $\left(1 \times 10^{5}\right.$ cells/well $)$ were seeded in 6-well plates containing DMEM media supplemented with $10 \%$ FBS. After attainment of $80 \%$ confluence, media was aspirated and a single scrape was made in a linear pattern through the centre of the plate to create a constant zone width across all wells. Then, cellular debris was removed by washing with PBS and the cells treated with doxorubicin $(1 \mu \mathrm{g} / \mathrm{mL})$ and $2 \mathrm{~d}(3 \mu \mathrm{g} / \mathrm{mL})$. Wound closure (in $\mu \mathrm{M})$ in each well after 24 and $48 \mathrm{~h}$ was measured using microscope stage micrometer and eye piece micrometer at $45 \mathrm{x}$ objective in each well and images were taken using a CCD camera (Nikon Eclipse TS100). The migration distance (average of triplicates) was computed by subtracting the width of injury line at $24 \mathrm{~h}$ or $48 \mathrm{~h}$ from the initial width of the injury line (at $0 \mathrm{~h}$ ) and expressed in $\mu \mathrm{m}^{20,21}$.

$$
\text { Migration distance }=\frac{\mathrm{A}-(\mathrm{B} \text { or } \mathrm{C} \text { or } \mathrm{D}) \times 100}{\mathrm{~A}}
$$

Where $\mathrm{A}=$ width of injury line at $0 \mathrm{~h} ; \mathrm{B}=$ width of injury line in the control; $\mathrm{C}=$ width of injury line at $24 \mathrm{~h} ; \mathrm{D}=$ Width of the injury line at $48 \mathrm{~h}$.

\section{Molecular modeling and docking studies}

Human Snaill crystal structure complexed with FAD (Flavine adenine dinucleotide) with corresponding entry code 2 Y 48 was recovered from the PDB database with a resolution of $3 \AA$. Protomol was generated for carrying out docking studies based on already complexed ligand residue, FAD using Surflex dock module of sybylver 1.7 licensed to Manipal Institute of Technology, Manipal University, India (Tripos Inc. St. Louis, USA). The ligands were built using ligand preparation module of surflex descriptors. The best favorable conformation in terms of highest docking score was chosen. The agreement of 2d to Lipinski's Ro5 was evaluated $^{22,23}$. 


\section{Results and Discussion}

FT-IR spectra of imidazolidinones recorded in $\mathrm{KBr}$ pellet using Shimadzu-8400S spectrometer showed a strong absorption band around $1700 \mathrm{~cm}^{-1}$ characteristic of $\mathrm{C}=\mathrm{O}$ stretching vibration. The absence of asymmetric and symmetric stretching vibration of $\mathrm{NH}_{2}$ groups at 3445 and $3200 \mathrm{~cm}^{-1}$ observed in Schiff bases clearly confirmed the formation of imidazolidinones. The ${ }^{1} \mathrm{H}-\mathrm{NMR}$ of imidazolidinones recorded in deuterated DMSO solvent and TMS as internal standard using Bruker spectrometer displayed a singlet downfield at $11.9 \mathrm{ppm}$ attributed to the proton attached to the nitrogen in the ring. The mass spectra of the compounds recorded in a Schimadzu GCMS-QP5050 mass spectrometer showed molecular ion peaks which were in accordance their respective molecular masses.

The $\mathrm{IC}_{50}$ for standard drug doxorubicin in HCT-116 cell line was $1.5 \pm 0.02 \mu \mathrm{g} / \mathrm{mL}$. 2d with hydroxyl and methoxy substituents exhibited minimum $\mathrm{IC}_{50}$ value of $21.6 \pm 0.7$ among all the imidazolidinones screened against HCT-116 cell line. 2a with a hydroxyl substituent and 2c with a methoxy group displayed comparatively higher $\mathrm{IC}_{50}$ values of $79.3 \pm 3.8$ and $39.5 \pm 2.7 \mu \mathrm{g} / \mathrm{mL}$ respectively. $2 \mathbf{b}$ with an indole substituent displayed an $\mathrm{IC}_{50}$ of $31.3 \pm$ $4.1 \mu \mathrm{g} / \mathrm{mL}$. All $\mathrm{IC}_{50}$ values are expressed as mean \pm SEM $(\mathrm{n}=3)$.

2d which displayed minimum $\mathrm{IC}_{50}$ value was further subjected to in vitro scratch wound healing assay to check the motility of HCT116 cells. Figure 1 displays the wound width after 24 and $48 \mathrm{~h}$ of wound infliction for control, doxorubicin $(1 \mu \mathrm{g} / \mathrm{mL})$ and $\mathbf{2 d}(3 \mu \mathrm{g} / \mathrm{mL})$. At the end of $24 \mathrm{~h}$, the wound gap in cells treated with $\mathbf{2 d}$ was almost same as that in the case of standard, showing its efficacy in restricting cell migration. Figure 2 illustrates cell migration across the wound for the control, standard $(1 \mu \mathrm{g} / \mathrm{mL})$ and $2 \mathbf{d}(3 \mu \mathrm{g} / \mathrm{mL})$ and clearly indicates the reduced motility of cells after $48 \mathrm{~h}$ following application of the wound, without any wound closure $(\mathrm{p}<0.05)$. Wound healing was observed with the control cells.

The best docking pose where 2d lies deep into the Snaill binding cavity representing the ligand-protein interaction and the binding mode is depicted in Figure 3. 2d showed hydrogen bonded interaction with the surrounding cage of amino acids within the binding pocket of Snaill. Docking of 2d resulted in high scoring orientations and favourable docking score of 5.54 presumably due to two H-bonds and also hydrophobic interactions with the receptor molecule. The oxygen and hydrogen of the hydroxyl group at the para position of the phenyl ring were H-bonded to hydrogen attached to the amino group of lysine (LYS) and oxygen attached to carboxyl group of leucine (LEU) respectively.

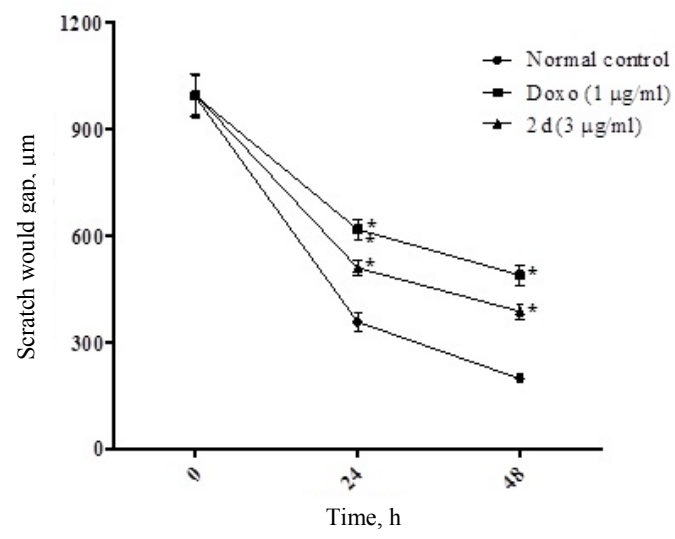

Figure 1. Graph depicting wound gap at the end of 24 and $48 \mathrm{~h}$ after wound infliction 


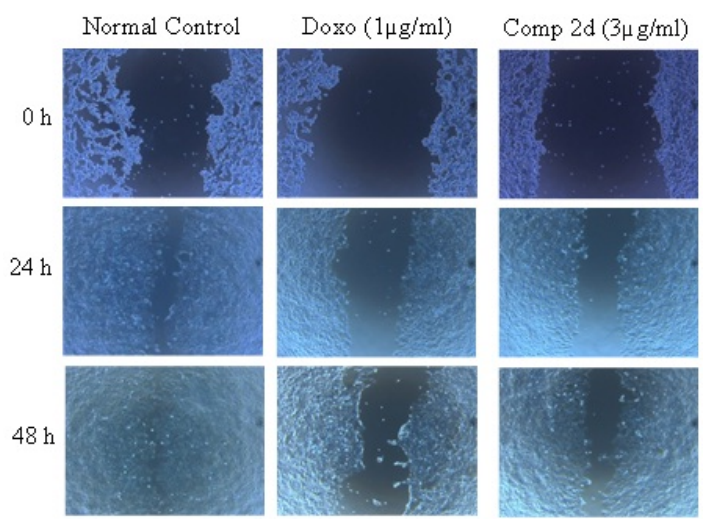

Figure 2. Picture displaying HCT 116 cell motility in in vitro wound healing assay. Control cells shows wound healing at $48 \mathrm{~h}$

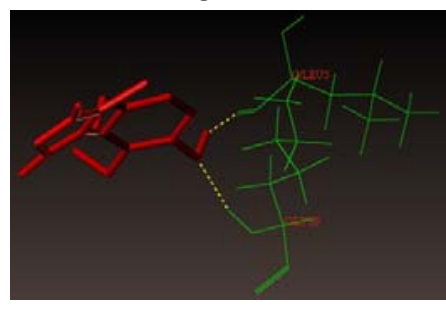

Figure 3. Binding of $\mathbf{2 d}$ into the active site of Snaill showing the hydrogen bonding interactions with the amino acid cage

The critical role of LSD1 in snail-dependent transcriptional repression of epithelial markers suggests that the LSD1-snaill complex could be a potential therapeutic target for prevention of EMT associated tumor invasion. 2d binds with the active site of snail-1 destabilizing the LSD1-Snail1 complex (Figure 4) and this could probably impair the repression activity of snail $1^{24,25}$.

Molecular weight greater than 500 Dalton and high numbers of Hydrogen bond acceptors $(>10)$ and donors $(>5)$ may weaken permeability across membrane bilayer. The Lipinski parameters for 2d (mol. wt- 265, LogP -1.64, HBA -4 and HBD -2) suggests that it might have better oral bioavailability. Polar surface area (PSA) for 2d was $106.25 \AA^{2}$, which is an indicator of its better intestinal permeability, absorption and passive transport.

General procedure for synthesis of 3-\{[(Z)-(4-substitutedphenyl)methylidene] amino\}-2-thioxoimidazolidin-4-one (2a-d)

0.01 mol of (2E)-2-(4-substituted)hydrazinecarbothioamide (Schiff bases) and 0.01 mol of ethylchloroacetate dissolved in ethanol was refluxed in presence of anhydrous sodium acetate on a water bath for 6 hours. The reaction mixture was poured into crushed ice. The solid separated was washed with cold water, filtered, dried and recrystallized from ethanol.

\section{3-[(E)-(4-Hydroxybenzylidene)amino]-2-thioxoimidazolidin-4-one (2a)}

Yellow solid (70\%) m.p.216-220 ${ }^{\circ} \mathrm{C}$; IR (KBr) $\left[\mathrm{cm}^{-1}\right]: 3471$ (OH str.), 3201 (NH str.), 3050 (Ar. C-H str.), 1720 ( $\mathrm{C}=\mathrm{O}$ str.), 1612(C=N str.), 1504 (Ar. C=C str.), 1234 (C=S str.); 
${ }^{1} \mathrm{H}$ NMR [ppm] DMSO-d 6 , 400MHz: $11.93(1 \mathrm{H}, \mathrm{NH}), 11.41(1 \mathrm{H}, \mathrm{CH}=\mathrm{N}), 7.7-8.2(4 \mathrm{H}, \mathrm{Ar}$. $\mathrm{H}), 3.75\left(2 \mathrm{H}, \mathrm{CH}_{2}\right), 7.54(1 \mathrm{H}, \mathrm{OH}) ; \mathrm{MS}(\mathrm{m} / \mathrm{z}): 235\left(\mathrm{M}^{+}\right)$; Anal. calcd. for $\mathrm{C}_{10} \mathrm{H}_{9} \mathrm{~N}_{3} \mathrm{O}_{2} \mathrm{~S} ; \mathrm{C}$, 51.06; H, 3.83; N, 17.87. Found: C, 51.20; H, 3.84; N, 17.89 .

3-[(E)-(2,3-Dihydro-1H-indol-3-ylmethylidene)amino]-2-thioxoimidazolidin-4-one (2b) Yellow solid (73 \%) m.p.172-178 ${ }^{\circ} \mathrm{C}$; IR (KBr) $\left[\mathrm{cm}^{-1}\right]$ : 3240 (N-H str.), 3109 (Ar. C-H str.), 1704 ( $\mathrm{C}=\mathrm{O}$ str.), 1620 (C=N str.), 1573 (Ar. $\mathrm{C}=\mathrm{C}$ str.), $1242\left(\mathrm{C}=\mathrm{S}\right.$ str.); ${ }^{1} \mathrm{H}$ NMR [ppm] DMSO-d $_{6}, 400 \mathrm{MHz}: 12.29(1 \mathrm{H}$, indole $\mathrm{NH}), 11.89(1 \mathrm{H}, \mathrm{NH}), 11.50(1 \mathrm{H}, \mathrm{CH}=\mathrm{N}), 7.6-8.1$ $\left(5 \mathrm{H}\right.$, Ar. H), $3.76\left(2 \mathrm{H}, \mathrm{CH}_{2}\right)$; MS (m/z): $258\left(\mathrm{M}^{+}\right)$; Anal. calcd. for $\mathrm{C}_{12} \mathrm{H}_{10} \mathrm{~N}_{4} \mathrm{OS}$; C, 55.81; H, 3.88; N, 21.71. Found: C, 55.93; H, 3.89; N, 21.73.

\section{3-[(E)-(2,3-Dimethoxybenzylidene)amino]-2-thioxoimidazolidin-4-one (2c)}

White solid (77\%) m.p.226-228 ${ }^{\circ} \mathrm{C}$; IR (KBr) $\left[\mathrm{cm}^{-1}\right]$ : 3155 (NH str.), 3047 (Ar. CH str.), 2909 ( $\mathrm{CH}_{3}$ asym. str.), 2831 ( $\mathrm{CH}_{3}$ sym. str.), 1712 ( $\mathrm{C}=\mathrm{O}$ str.), 1596 ( $\mathrm{C}=\mathrm{N}$ str.), 1542 (Ar. $\mathrm{C}=\mathrm{C}$ str.), 1265 (C=S str.); ${ }^{1} \mathrm{H}$ NMR [ppm] DMSO-d $6,400 \mathrm{MHz}: 11.92(1 \mathrm{H}, \mathrm{NH}), 11.43(1 \mathrm{H}, \mathrm{CH}=\mathrm{N})$, 7.7-8.2 (3H, Ar. H), $3.79\left(2 \mathrm{H}, \mathrm{CH}_{2}\right), 3.48\left(3 \mathrm{H}, \mathrm{OCH}_{3}\right), 3.42\left(3 \mathrm{H}, \mathrm{OCH}_{3}\right) ; \mathrm{MS}(\mathrm{m} / \mathrm{z}): 279\left(\mathrm{M}^{+}\right)$ $\mathrm{C}_{12} \mathrm{H}_{13} \mathrm{~N}_{3} \mathrm{O}_{3} \mathrm{~S} ; \mathrm{C}, 51.61 ; \mathrm{H}, 4.66 ; \mathrm{N}, 15.05$. Found: $\mathrm{C}, 51.69 ; \mathrm{H}, 4.68 ; \mathrm{N}, 15.08$.

\section{3-[(E)-(4-Hydroxy-3-methoxybenzylidene)amino]-2-thioxoimidazolidin-4-one (2d)}

Yellowish green (76\%) m.p.260-262 ${ }^{\circ} \mathrm{C}$; IR ( $\left.\mathrm{KBr}\right)\left[\mathrm{cm}^{-1}\right]: 3556$ (OH str.), 3200 (NH str.), 3110 (Ar. CH str.), 2923 ( $\mathrm{CH}_{3}$ asym. str.), 2880 ( $\mathrm{CH}_{3}$ sym. str.), 1697 (C=O str.), 1596 (C=N str.),1550 (Ar. $\mathrm{C}=\mathrm{C}$ str.), 1288 ( $\mathrm{C}=\mathrm{S}$ str. $) ;{ }^{1} \mathrm{H}$ NMR [ppm] DMSO-d 6 , $400 \mathrm{MHz}: 11.91(1 \mathrm{H}$, $\mathrm{NH}), 11.42(1 \mathrm{H}, \mathrm{CH}=\mathrm{N}), 7.7-8.2(3 \mathrm{H}, \mathrm{Ar} . \mathrm{H}), 3.8\left(3 \mathrm{H}, \mathrm{OCH}_{3}\right), 3.75\left(2 \mathrm{H}, \mathrm{CH}_{2}\right), 7.95(1 \mathrm{H}$, $\mathrm{OH}) ; 265\left(\mathrm{M}^{+}\right)$; Anal. calcd. for $\mathrm{C}_{11} \mathrm{H}_{11} \mathrm{~N}_{3} \mathrm{O}_{3} \mathrm{~S} ; \mathrm{C}, 49.81 ; \mathrm{H}, 4.15 ; \mathrm{N}, 15.85$. Found: $\mathrm{C}, 49.92$; $\mathrm{H}, 4.14 ; \mathrm{N}, 15.88$.

\section{Conclusion}

Four new imidazolidinones were synthesized by cyclization reaction of Schiff bases with ethylchloroacetate. The different spectral techniques and the elemental analysis confirmed the structure of the compounds. This study reveals 3-[(E)-(4-hydroxy-3methoxybenzylidene)amino]-2-thioxoimidazolidin-4-one to be a potent cytotoxic and antimigratory agent as well as a novel antimetastatic snaill inhibitor against colorectal adenocarcinoma cells.

\section{Acknowledgement}

The authors are grateful to Director and Head-Department of Chemistry and Biotechnology, Manipal Institute of Technology, Manipal University for providing us the necessary laboratory facilities.

\section{References}

1. Nieto M A, Nat Rev Mol Cell Biol., 2002, 3(3), 155; DOI:10.1038/nrm757

2. Kajita M, McClinic K N and Wade P A, Mol Cell Biol., 2004, 24(17), 7559-7566; DOI:10.1128/MCB.24.17.7559-7566.2004

3. Savagner P, Kusewitt D F, Carver E A, Magnino F, Choi C, Gridley T and Hudson L, J Cell Physiol., 2005, 202, 858-866; DOI:10.1002/jcp.20188

4. Thiery J P, Nat Rev Cancer, 2002, 2, 442; DOI:10.1038/nrc822

5. Nieto M A, Sargent M, Wilkinson D G and Cooke J, Science, 1994, 264, 836-840;

6. Rosivatz E, Becker I, Specht K, Fricke E, Luber B, Busch R, Hofler H and Becker K F, Am J Pathol., 2002, 161(5), 1881-1891. 
7. Palmer, H G, Larriba M J, Garcia J M, Ordonez-Moran P, Pena C, Peiro S, Puig I, Rodriguez R, de la Fuente R, Bernad A, Pollan M, Bonilla F, Gamallo C, Garcia de Herreros A and Munoz A, Nat Med., 2004, 10, 917-919; DOI:10.1038/nm1095

8. Peinado H, Marin F, Cubillo E, Stark H J, Fusenig N, Nieto M A and Cano A, J Cell Sci., 2004, 117(13), 2827-2839; DOI:10.1242/jcs.01145

9. Kumar S, Niranjan M S, Chaluvaraju K C, Jamakhand C M and Kadadevar D, J Current Pharm Res., 2010, 1(1), 39-42.

10. Abdullah M A and Salman A K, Molecules, 2010, 15, 6850.

11. Omprakash G B, Sainath B Z, Shivaji B C and Yeshwant B V, J Chem Pharm Res., 2010, 2, 234.

12. Omprakash G B, Sainath B Z, Shivaji B C and Yeshwant B V, J Chem Pharm Res., 2010, 2(6), 234-243;

13. Cheng L X, Tang J J, Luo H, Jin X, Dai F, Yang J, Qian Y P, Li X Z and Zhou B, Biorg Med Chem Lett., 2010, 20(8), 2417-2420; DOI:10.1016/j.bmcl.2010.03.039

14. Lydia S, Samia B, Yamina B, Yamina B, Sophie P, Bastien C, Elisabet D and Bellara N, Org Commun., 2013, 6(2), 87

15. Arora K, VermaS, Joshi R, Pardasani P and Pardasani R T, Indian J Chem.., 2011, 50B, 83-88.

16. Shama V K, Lee K C, Joo C, Sharma N and Jung S H, Bull Korean Chem Soc., 2011, 32(8), 3009-3016.

17. Dhanya S, Isloor A M, Shetty P, Chankrakantha B and Satyamoorthy K, Med Chem Res., 2011, 20(7), 1024-1032; DOI:10.1007/s00044-010-9433-z

18. Abd El-Fattah M E, Indian J Chem., 2006, 45B, 2523.

19. Skehan P, Storeng R, Scudiero D, Monks A, McMahon J, Vistica D, Warren J T, Bokesch H, Kenney S and Boyd M R, J Natl Cancer Inst., 1990, 82(13), 1107-1112; DOI:10.1093/jnci/82.13.1107

20. Hostanska K, Nisslein T, Freudenstein J, Reichling J and Saller R, In Vivo, 2007, 2, 1349-1356.

21. Vaid M, Singh T and Katiyar S K, PLOS One, 2011, 6, e21539.

22. Umarani N, Ilango K and Ishwarya T, Indian J Pharm Edu Res., 2012, 46(4), 366.

23. Lipinski C A, J Pharm Toxicol Methods, 2008, 44(1), 235-249;

DOI:10.1016/S1056-8719(00)00107-6

24. Lin T, Ponn A, Hu X, Law B K and Lu J, Oncogene, 2010, 29(35), 4896-4904; DOI:10.1038/onc.2010.234

25. Lin Y, Wu Y, Li J, Dong C, Ye X, Chi Y I, Evers B M and Zhou B P, Embo J., 2010, 29(11), 1803-1816. 